\title{
Jane \& Theo: Affinities Stylistic and Temperamental in Jane Austen and Theodor Fontane
}

\begin{abstract}
Inhabiting different historical periods, and separated by linguistic, cultural, and literary traditions, Jane Austen and Theodor Fontane seem unlikely candidates for fruitful comparative treatment. The predominance in Germany of the Bildungsroman emphasizes the inner development of the individual; it is Fontane who moves the German novel into the European mainstream by representing characters engaged in life, rather than in meditation or art. If Austen's interests lie in social customs embodied in the novel of manners, Fontane later initiates a teutophone version of the genre, with the work of Thackeray at mid-century being, this article proposes, a crucial go-between.

From a common attraction to the topics of courtship and marriage, of deceptive appearances, of small-scale events in realistically observed contemporary settings where women prevail over men, similar authorial attitudes are evident. Austen and Fontane exploit various forms of irony to mock excesses of sentiment and feeling, illustrated in the play of dialogue and the artifice of conversation. With literary styles exhibiting lucidity, balance, and order, each writer projects common sense, reserve, and moderation, issuing from a core outlook of restraint. This prevents their critiques from becoming polemic, and their irony from darkening into caricature, and ultimately assures Austen and Fontane of the high regard in which they are held as novelists.
\end{abstract}

Keywords: dialogue, irony, novel of manners, restraint, social codes, Thackeray

Theodor Fontane to his wife, from London, 10 July 1852: "Meine liebe HerzensMila, ich habe neulich die Romane von Jane Austen entdeckt: humorvoll, scharfsichtig, reizend, meine Vorbilder fortan." Sadly, this letter has not yet been discovered, depriving critics of the chance to pursue scholarly commentaries on the relationship between the two authors. Austen and Fontane in fact never met. Her death in 1817 and his birth in 1819 prevented this. No reference to her is found anywhere in his works, making traditional influence studies problematic. ${ }^{1}$ Intri-

1 Few studies touch on the relationship between Austen and Fontane; exceptions include Demetz (1964), Grawe (1988), and Chambers (1997), while a dissertation by Holznagel (1956), and an online contribution by Botrall (2013), virtually complete the list. 
guingly, Fontane did write to Emilie on 20 July 1852, recommending "ein höchst interessantes Buch” (Fontane 1976-1994, 1: 292; emphasis in original): W. M. Thackeray's Vanity Fair, described by one of Fontane's biographers as the "Muster des Gesellschaftsromans schlechthin” (Reuter 1968, 1: 275).

In his Princeton address of 1939 on the art of the novel, Thomas Mann declared that the nineteenth-century German-language novel was not European enough since it was not a Gesellschaftsroman, a genre "landfremd" in Germany, with the exception of Fontane's work, especially his Effi Briest (1895; Mann 1974, 360-361). Fontane's unique role is due largely to the fact that he was the only major German-language novelist in the nineteenth century to cross the Channel. He visited England three times, for two weeks in 1844, six months in 1852, and for three-and-a-half years between 1855 and 1859. As press correspondent in London, he had extensive access to a culture he wished to emulate in Prussia. His admiration for the historical novels and ballads of Sir Walter Scott is well attested, and clearly influenced his own first novel, Vor dem Sturm (1878); his travels to Scotland inspired the travel genre of Jenseit des Tweed (1860), triggering his later Wanderungen durch die Mark Brandenburg (1862-1882). It was his lengthy stays in England in the 1850s, however, which were to prove decisive for Fontane's fiction, and the topic of England itself, important in Cécile (1887), Unwiederbringlich (1892), and Frau Jenny Treibel (1893), continued into his last novel, Der Stechlin (1897), published in the year prior to his death in 1898.

After her death in 1817, Jane Austen's fortunes were largely affected by the overwhelming success of Sir Walter Scott. In the era of romanticism, her novels lost favour, but, by the 1850s, Austen had been rediscovered by George Henry Lewes, George Eliot's companion, and by Lord Macaulay, both of whom compared her to Shakespeare. Though French translations appeared early on, only two of her novels were translated into German, followed by a huge gap until the 1930s (Bautz 2007a, 93-116). By the 1870s, when her nephew, James Edward Austen-Leigh, published his biographical Memoir of Jane Austen, and Lesley Stephen, father of Virginia Woolf, coined the term “Austenolatry," her reputation began to recover, though in terms of printed editions and library holdings, Scott was to keep his lead until 1914 (Bautz 2007b).

Fontane's literary essays on non-German writers range from Fielding and Sterne, Scott and Dickens, to Zola and Thackeray. Those names reappear among the seventy-one authors listed in his "Die besten Bücher” of 1889 (Fontane 19591975, 21.1: 497-499). Austen's name is absent; with her reputation still at a low ebb when Fontane was in England in the 1850s, this is not too surprising. As is evident from his articles on British life and culture, his theatre reviews, and his perceptive and liberal-minded journalism, Fontane is temperamentally and linguistically well equipped to register the mood and ambience of his adopted coun- 
try. He recognizes, for instance, the importance of the stage in expressing societal relationships, and appreciates the incisive prose style of the Times newspaper and the wit and humour of Punch magazine, founded, as it happens, by Thackeray (see Reuter 1968, 1: 326-334).

The New Historicist critic Stephen Greenblatt cites the examples of Goethe and Shakespeare to illustrate the creative mobilization of cultural materials, points out the role of hidden as well as conspicuous movements, and stresses the need to identify and analyse the "contact zones" where cultural goods are exchanged (Greenblatt 2010, 1-23, 75-95, 250-253). For Austen and Fontane, the relevant contact zone is the 1850s, with Thackeray as transcultural intermediary in his role of continuing Austen's novel of manners. Isolated in a Swiss village in 1859, Thackeray writes that he has "been living at Bath for the last 10 days in Miss Austen's novels which have helped me to carry through a deal of dreary time" (The Letters and Private Papers of William Makepeace Thackeray 1946, 4: 155). Elsewhere, he concedes that as a humorist he could not sustain "the controlled understatement of an Austen” (quoted in Kiely 1987, 17), though for contemporary reviewers his lifelike characters are matched only by Jane Austen. Both writers resort to parody in their earliest fictions - of the Gothic novel in Austen's Northanger Abbey (begun in 1798), and of the Newgate novel in Thackeray's Catherine (1840) - while the eighteenth century provides the period setting for many of Thackeray's writings. For one critic, Austen's spirit is clearly echoed in Thackeray: "There is the same criticism of life; the hatred of shams [...] the quick irony [...] the delightful turns of expression [...] the caustic word [...] the humour, half genial and half sardonic." In pathos, however, he out-distances her completely: "in 1850 writers did not deem it necessary to disguise their tenderer feelings, and in 1811 they did" (Dawson 1905, 43).

Fontane's attraction to Vanity Fair, and his experience of mid-Victorian culture largely determine his novelistic direction. ${ }^{2}$ The predominance in German literature of the Bildungsroman or Entwicklungsroman, exemplified by Goethe's Wilhelm Meister, and continued by Gottfried Keller and Adalbert Stifter, with its focus on the inner growth of personality, is scarcely challenged until Fontane emerges. Austen's legacy of the comedy of manners, which explores the relationships between individuals and society, is taken up by Thackeray in his wider panoramic survey of the fashionable world. In later life, Fontane regrets the lack of a comparable Berlin novel, "etwa wie Thackeray in dem besten seiner Romane Vanity Fair in einer alle Klassen umfassenden Weise das Londoner Leben geschildert hat"

2 For a more detailed account of the relationship between Fontane and Thackeray, especially between Vor dem Sturm and Vanity Fair, see Eberhardt (1975). 
(Fontane 1959-1975, 21.2: 653). It is Thackeray's humour and realistic observation, as well as his own two hundred illustrations for Vanity Fair, which appeal; though both Thackeray and Dickens, Fontane notes, foreground society's corruption and hypocrisy.

When Peter Demetz, one of his most persuasive critics, refers to Fontane's "Roman der guten Gesellschaft," he characterizes the "good society" element as "eine bewegliche ästhetische Kategorie" (Demetz 1964, 123), thereby validating the concept of emigration across divides of time, language, and nationality. It is significant that in the England of the 1850s, the Prussian journalist is drawn not by the social-realist novels of Elizabeth Gaskell or the atmospheric romanticism of the Brontës, but by the historical works of Scott and by Thackeray's humorous societal world. As one of the few critics to link Austen and Fontane, Demetz alludes to an intimate scale and refined technique when he terms Fontane "der Meister des Silberstiftes, der einzige deutsche Bundesgenosse Jane Austens und Henry James" (Demetz 1964, 85). In the "Roman der guten Gesellschaft," Demetz points to the fine shades and subtleties of a realm where the implicit replaces the circumstantial: "Es ist, von Jane Austen bis Fontane, die Welt der 'richtigen Adresse'. Erzähler und Leser [...] kennen die Schichtungen, Abweichungen und Nuancen; es bedarf allein der Anspielung, nicht der ausführlichen Beschreibung und Lokalfarbe" (Demetz 1964, 117).

Austen's exquisite touch, knowledge of the human heart, and capture of "real life" are qualities which Scott himself emphasizes (Halperin 1984, 290-291), so that her brand of domestic realism marks her off from the excesses of Gothic and the emotionalism of the Romantics. Later in the century, Fontane notes the "objective" theories of Friedrich Spielhagen, which declare that the author should not directly intrude into the novel but represent characters through their speech and actions, though Fontane is reluctant to discard narratorial presence entirely. His approach to mimesis, in the age of Flaubert and Zola, is moderate and restrained, even if his use of concrete detail eclipses Austen's: we learn, for instance, that Krola in Frau Jenny Treibel (1893) accompanies lieder from Schubert's Die schöne Müllerin and a duet from Mozart's The Marriage of Figaro, but we are ignorant of what Mary Bennet sings in Pride and Prejudice (1813). While Austen embraces universal and moral concerns, with a bias towards generality, Fontane's focus on dialogue results in a similar reduction of external detail: "Bei beiden leben die Personen so aus ihrer eignen Sprache, daß die Autoren auf ihre äußere Beschreibung weitgehend verzichten” (Grawe 1988, 173).

Both Austen and Fontane register what Angus Wilson calls "felt sociology" $(1967,190)$ in treating individuals and communities. The spatial and thematic range of Fontane's novels includes contemporary, middle-class Berlin, sometimes expanding into the Mark Brandenburg; seascapes appear in Effi Briest (1895); Graf 
Petöfy (1884) deals with Viennese society, and Unwiederbringlich (1892) with Danish aristocracy. Austen's "3 or 4 Families in a Country Village” (Jane Austen's Letters 2011, 287), however, might live anywhere between Hampshire and Yorkshire, since topographical and historical specifics are not key, and she leaves travelogues to other writers: "It is not the object of this work [Pride and Prejudice] to give a description of Derbyshire, nor of any of the remarkable places through which their route thither lay" (Austen 2006b, 266). As Demetz points out, "Bei Jane Austen und Fontane fährt man ab und kommt an; die Reisen fallen, wie auf der Komödienbühne, in die Pausen” (Demetz 1964, 118). Like Austen, Fontane operates within self-chosen limits, concentrating on the depiction of manners, even if in his first novel, Vor dem Sturm (1878), he echoes Vanity Fair, employing historical material from the Napoleonic period. For Austen, her famous self-chosen limits involve "the little bit (two Inches wide) of Ivory on which I work with so fine a Brush" (Jane Austen's Letters 2011, 337), and she is disinclined to stray beyond familiar bounds: "I am fully sensible that an Historical Romance, founded on the House of Saxe Cobourg, might be much more to the purpose of Profit or Popularity, than such pictures of domestic Life in Country Villages as I deal in - but I could no more write a Romance than an Epic Poem" (326).

In a review of Gustav Freytag's novel cycle Die Ahnen (1872-1880), Fontane stresses the values of moderation, credibility, and contemporaneity desirable in a novel; he might almost be describing Austen's work: “[Der Roman] soll uns, unter Vermeidung alles Übertriebenen und Häßlichen, eine Geschichte erzählen, an die wir glauben [...] soll uns eine Welt der Fiktion auf Augenblicke als eine Welt der Wirklichkeit erscheinen [...] lassen" (Fontane 1959-1975, 21.1: 239; emphasis in original). Unlike the English novelist, who eschews comment on the great political events of her day, and has Catherine Morland and Henry Tilney in Northanger Abbey avoid the topic of politics since "it was an easy step to silence" (Austen 2006a, 113), the Prussian has a firm basis in Bismarck's Gründerzeit, but his journalistic experiences and social critiques are never manifested in the kind of caustic satire favoured by Thackeray. The social structure of Austen's country gentry is also distinct from the contrast between established and emerging classes in Fontane. Her servants are barely seen; in Emma, the yeoman farmer Robert Martin, of whom the title-figure disapproves, is never granted speech, while she snubs the Coles, the Tupmans, and Mrs Elton by reason of their "low origins." With Fontane, servants play relatively important roles: in Frau Jenny Treibel, Friedrich mediates between Leopold and his mother, and Frau Schmolke influences Corinna; in Die Poggenpuhls (1896), Friederike shows warm appreciation of the title-family.

For both writers, the crucial yardsticks are good breeding and decorum, invested in the English gentry and upper classes, or in the Prussian Junker class, which Fontane admires but also criticizes - in Effi Briest, for the inflexibility of its 
social code. The importance of order and stability is reflected in communal forms and customs: in both Austen and Fontane, characters come together over meals, and at the social rituals of walks, rides, excursions, picnics, spas, or balls, which also serve, in terms of architectonic structure, to articulate narratives and create sequential rhythms. The motif of the Landpartie, for instance, exemplifies the "Roman der guten Gesellschaft," while both writers frame their societal events in four distinct phases: preparations and arrivals; the event itself; the return home; and reflective post-mortems. Episodes of passion, which Fontane calls "der Gipfel der Geschmacklosigkeit” (1976-1994, 4: 455), are carefully avoided by both novelists. As Christian Grawe, Austen's biographer and translator, points out, extremes of any kind are taboo: "Jane Austen verzichtet wie Fontane auf Sensationen, [...] Geburt, Krankheit und Tod, Sexualität und Laster werden von beiden mit äußerster Diskretion behandelt” (1988, 173-174). The scene in the palm house between Melanie and Rubehn in L'Adultera (1882), which threatens to become torrid, only illustrates the power of narrative silence and ellipsis at potentially awkward moments.

In the early Vor dem Sturm, Faulstich declares that books do not guarantee happiness, and cautions against being deceived by the appearance of life, the “Lüge des Daseins” (Fontane 1959-1975, 1: 182). In Northanger Abbey, Catherine Morland allows books to govern her life; in Sense and Sensibility, Marianne Dashwood's emotions take over; while vanity rules Emma Woodhouse. All three show the folly of trusting in appearances, but by ironic distancing, Jane Austen employs their deviations from norms of good sense and moderation for humorous and moral purposes. Although Jenny Treibel's idealism actually conceals a practical ambition, and Corinna in the eponymous novel overcomes her "Sinn für Äußerlichkeiten” (Fontane 1959-1975, 7: 161), Fontane is elsewhere occupied with more serious aspects of appearances. Less at ease in his contemporary world than Austen, Fontane senses its pretence and falsity all the more keenly: "Wir stecken ja bis über die Ohren in allerhand konventioneller Lüge und [wir] sollten uns schämen über die Heuchelei, die wir treiben, über das falsche Spiel, das wir spielen” (Fontane 1976-1994, 3: 559). It is on the social institution of marriage that he focuses, in order to dramatize the role of appearances and society's demands on individuals. Thus, Effi Briest's engagement to Baron Instetten is announced as early as the novel's first day, in chapter 3, so that the body of the text thereafter concerns the fate of that marriage, of désamour, temptation, divorce, and guilt.

With Austen, courtship itself, the choice of possible partners, is more central, abetted by playful suspense and carefully laid false trails, but with contenders usually from the same social stratum. In Pride and Prejudice, for instance, "that continual breach of conjugal obligation and decorum” (Austen 2006b, 262-263) 
between Mr Bennet and his wife, nowhere approaches the serious marital issues witnessed in Fontane, especially when partners, as is frequently the case, belong to different social classes: aristocratic, lower-middle, or artisan levels. For Fontane, brief liaisons thus seem almost less dangerous and serious than marriages lacking in sincerity and understanding. Only the most independent-minded resist the pressures of society; Fontane's women may be limited or conventional, but can be decisive, and his perspective is consistently that of the female domestic sphere in a male-dominated society. Austen's heroines predominate, her heroes tend to conceal their feelings, and her villains are presented as clever and unprincipled; Fontane's men, like Graf Botho in Irrungen Wirrungen (1888), tend to be indecisive and accepting. Austen's relatively happy endings also contrast with Fontane's more problematic and qualified resolutions.

Stylistically, Fontane challenges the pompous, cliché-ridden language of Bismarck's materialistic Gründerzeit, by adopting a clipped, transparent prose style, shunning sentimentality and pathos. In her own undermining of pretentiousness and affectation, Austen is concerned less with a specific historical period than with general human folly, while her more secure society encourages her more consistently ironic viewpoint. Her distaste for hackneyed expression is illustrated in Mary Bennet's reaction in Pride and Prejudice to her sister Lydia's elopement: "we must stem the tide of malice, and pour into the wounded bosoms of each other, the balm of sisterly consolation" (Austen 2006b, 319). Fontane's range of register, unlike Austen's, is enriched by colloquial and regional lexis, as well as frequent Fremdwörter, which in the mouth of Gideon Franke in Irrungen Wirrungen have comic effects: "Ja, Herr Baron, auf die Proppertät kommt es an und auf die Honnettität kommt es an, und auf die Reellität” (Fontane 1959-1975, 3: 205). Wit is often allied with laconic phrasing: Mr Woodhouse is encapsulated as a "valetudinarian all his life" (Austen 2005, 5), while Adelheid's visit in Der Stechlin is presented as "kein Nachmittagsbesuch, sondern Einquartierung" (Fontane 1959-1975, 8: 320).

By subtle rephrasing or shift of tense, Austen records fine shades of meaning, and transposes a passage into a key of irony, as in Emma's meeting with Harriet Smith: "To walk by the side of this child, and talk to and question her, was the most natural thing in the world, or would have been the most natural, had she been acting just then without design" (Austen 2005, 95; my emphasis). In Frau Jenny Treibel, we find a similar type of dry irony, reformulating a statement: Leopold and Corinna "hatten ihr Gespräch in herkömmlicher Art geführt, das heißt Corinna hatte gesprochen" (Fontane 1959-1975, 7: 109). Fontane's resort to dramatic irony, as in Effi Briest's cautions to her maid about intimacies with a married man, recalls the many blind judgements on human relationships by Emma Woodhouse. 
Syntactic anticlimax, as a rhetorical device, is used by both novelists to project a critique of human foibles. Appearance belies actuality when we witness a rapid shift from one emotion to its opposite, as is the case in Northanger Abbey, where Mrs Thorpe encounters Mrs Allen: "Their joy on this meeting was very great, as well it might, since they had been contented to know nothing of each other for the last fifteen years" (Austen 2006a, 24): the suggestion of superficial friendship is not lost. With Fontane, in Frau Jenny Treibel, the same device of syntactic anticlimax is employed to target bourgeois materialism: "Krola war seit fünfzehn Jahren Hausfreund, worauf ihm dreierlei einen gleichmäßigen Anspruch gab: sein gutes Äußere, seine gute Stimme und sein gutes Vermögen" (Fontane 1959-1975, 7: 23). In Marianne Dashwood's impression of John Willoughby in Sense and Sensibility, the reader perceives that any objective appraisal is compromised by subjective reaction: "His name was good, his residence was in their favourite village, and she soon found out that of all manly dresses a shooting-jacket was the most becoming” (Austen 2006c, 51; my emphasis). Dörr's subjective reaction in Irrungen Wirrungen, when his favourite cock is chased up the pear tree, illustrates Fontane's inclination towards situational humour, often bordering on farce, at a remove from Austen's practice: 'Himmeldonnerwetter,' schrie Dörr in Wut, 'das is wieder Bollman seiner ... Wieder durch den Zaun ... I, da soll doch ...”' (Fontane 1959-1975, 3: 100).

The self-conscious use of language by both writers is realized not only by irony, but also in the handling of dialogue, as opposed to external description, and in the relatively large role of speech in novels such as Emma ( $58 \%$ of the text) and Die Poggenpuhls (60 \%). Conversation, although characters themselves recognize it as artifice, nonetheless functions as the essential fuel of society. Beneath the surface flow of words may lie emptiness or a scepticism about the value of conversation itself. Graf Botho, in Irrungen Wirrungen, for example: "eigentlich ist es ganz gleich, wovon man spricht. [...] Italien oder Paris oder die Stadtbahn, oder ob die Panke zugeschüttet werden soll. Es ist alles ganz gleich" (Fontane 1959-1975, 3: 112). His tone reminds us of John Knightley's amusing comments on the folly of "setting forward to spend five dull hours in another man's house, with nothing to say or to hear that was not said and heard yesterday, and may not be said and heard again tomorrow" (Austen 2005, 122).

Dialogue also tends to foreground the character of the speaker rather than what he or she says, as in the "nonstop burble" of Miss Bates's virtual monologues in Emma, which retail gossip and rumour in disjointed bursts of speech. Like Austen, Fontane is aware of the essential artifice of the conversational "situation." For Jenny Treibel, age is immaterial, since the crucial issues in society are primarily "Konversation und Augenausdruck und namentlich die 'Welt der Formen”" (Fontane 1959-1975, 7: 16). In his last novel, Der Stechlin, especially, Fon- 
tane's characters are highly self-conscious about the language they use, weighing up alternative expressions and, in a largely plot-free text, making dialogue and conversation themselves into topics of conversation by referring to "Lieblingsthema," "Gesprächsstoff," and "Fremdwörterschatz." Peter Demetz, indeed, claims that the "dramatic" organization of Fontane's Gesellschaftsromane of 1880-1895 emulates Jane Austen in terms of "die dialektische Verschränkung von Ereignis und Figur; Wendung und Umschlag; die vorzugsweise innere Motivierung; die vollständige Transparenz der Figuren erst im letzten Wort” $(1964,179)$.

Understatement implies by its reticence something left unsaid, to be supplied by the reader. Both writers feature, in contemporary settings, events that are small in scale, though not small in significance. Fontane admits that he tries to deal first and quickly "mit den sogenannten Hauptsachen [...] um bei den Nebensachen liebevoll, vielleicht $z u$ liebevoll verweilen zu können” (Fontane 1976-1994, 4: 46; emphasis in original). Small visual gestures stand out: Treibel leaning back in his chair blowing smoke-rings and Otto balancing a teaspoon on his index finger in Frau Jenny Treibel, while at the end of Effi Briest, Wüllersdorf advises Instetten to celebrate the small things in life: "im kleinen und kleinsten so viel herausschlagen wie möglich” (Fontane 1959-1975, 7: 420). Seemingly trivial incidents can be crucial, even if neglected by a title-figure: "Much that lived in Harriet's memory, many little particulars of the notice she had received from [Knightley], a look, a speech, a removal from one chair to another, a compliment implied, a preference inferred, had been unnoticed, because unsuspected by Emma" (Austen 2005, 446). Virginia Woolf observes that "what [Austen] offers is, apparently, a trifle, yet is composed of something that expands in the reader's mind and endows with the most enduring form of life scenes which are outwardly trivial” (1984, 138-139).

Even given the huge disproportion in quantity between the collected work of Fontane over his seven decades, and the very modest production of Austen over her four, it is nonetheless possible to detect a shared attitude of restraint, manifest in values of common sense and discretion, which prevents both writers from veering towards extremes. In the Romantic era of Byron and Wordsworth, Austen's values of lucidity and balance, her observance of eighteenth-century classical unities, often cast her in an anachronistic light, while Fontane, in the last quarter of the century, writes his societal novels in a period of naturalism, aestheticism, symbolism, and fin-de-siècle decadence, lending his own work a similar sense of anachronism. To write novels of manners in the 1810s, and Gesellschaftsromane in the 1880s and 1890s, may go against the grain of contemporary trends. If the cost of creating literary masterpieces is being labelled anachronistic, however, it is not the worst of insults. Austen and Fontane bravely overcome this stigma; the result: the best of novels. 


\section{Works cited}

Austen, Jane. Emma. Ed. Richard Cronin and Dorothy McMillan. Cambridge: Cambridge University Press, 2005. Cambridge Edition of the Works of Jane Austen.

Austen, Jane. Northanger Abbey. Ed. Barbara M. Benedict and Deirdre Le Faye. Cambridge: Cambridge University Press, 2006a. Cambridge Edition of the Works of Jane Austen.

Austen, Jane. Pride and Prejudice. Ed. Pat Rogers. Cambridge: Cambridge University Press, 2006b. Cambridge Edition of the Works of Jane Austen.

Austen, Jane. Sense and Sensibility. Ed. Edward Copeland. Cambridge: Cambridge University Press, 2006c. Cambridge Edition of the Works of Jane Austen.

Bautz, Annika. "The Reception of Jane Austen in Germany." The Reception of Jane Austen in Europe. Ed. Anthony Mandal and Brian Southam,. London: Continuum, 2007a. 93-116.

Bautz, Annika. The Reception of Jane Austen and Walter Scott: A Comparative Longitudinal Study. London: Continuum, 2007b.

Botrall, Ingeborg. “Kriterien für einen guten Roman.” Theodor Fontane Gesellschaft. 2013. https://fontane-gesellschaft.de/2013/08/10/kriterien-fuer-einen-guten-roman/ (20 February 2016).

Chambers, Helen. The Changing Image of Theodor Fontane. Columbia: Camden House, 1997.

Dawson, W. J. The Makers of English Fiction. London: Hodder \& Stoughton, 1905.

Demetz, Peter. Formen des Realismus: Theodor Fontane, Kritische Untersuchungen. Munich: Hanser, 1964.

Eberhardt, Wolfgang. Fontane und Thackeray. Heidelberg: Winter, 1975.

Fontane, Theodor. Sämtliche Werke. Ed. Edgar Gross. 24 vols. Munich: Nymphenburger Verlagshandlung, 1959-1975.

Fontane, Theodor: Briefe. Ed. Otto Drude and Helmuth Nürnberger. 5 vols. Abteilung 4 of Theodor Fontane: Werke, Schriften und Briefe. Munich: Hanser, 1976-1994.

Grawe, Christian. Jane Austen. Stuttgart: Reclam, 1988.

Greenblatt, Stephen. Cultural Mobility: A Manifesto. Cambridge: Cambridge University Press, 2010.

Halperin, John. The Life of Jane Austen. Brighton: The Harvester Press, 1984.

Holznagel, Siegfried. “Jane Austen's Persuasion and Der Stechlin: Eine vergleichende morphologische Untersuchung.” Diss. Universität Bonn, 1956.

Kiely, Robert. “Victorian Harlequin: The Function of Humor in Thackeray's Critical and Miscellaneous Prose.” William Makepeace Thackeray. Ed. Harold Bloom. New York: Chelsea House Publishers, 1987. Modern Critical Views. 5-20.

Jane Austen's Letters. Ed. Deirdre Le Faye. 4th ed. Oxford: Oxford University Press, 2011.

The Letters and Private Papers of William Makepeace Thackeray. Ed. Gordon N. Ray. 4 vols. London: Oxford University Press, 1946.

Mann, Thomas. “Die Kunst des Romans.” Reden und Aufsätze. By Mann. Vol. 10 of Gesammelte Werke. Frankfurt am Main: Fischer, 1974. 13 vols. 1974. 348-362.

Reuter, Hans-Heinrich. Fontane. 2 vols. Munich: Nymphenburger Verlagshandlung, 1968.

Wilson, Angus. "Evil in the English Novel." Kenyon Review 29.2 (1967): 167-194.

Woolf, Virginia. The Common Reader. Ed. Andrew McNeillie. First series. London: Hogarth Press, 1984. 
Ken Ireland's publications include many articles on comparative, transcultural, and narratological topics, plus three books: The Sequential Dynamics of Narrative (2001), Cythera Regained? The Rococo Revival in European Literature and the Arts, 1830-1910 (2006), and Thomas Hardy: Time and Narrative (2014). He has lectured in the US, Nigeria, and Japan, and been involved in adult education in the UK for the Open University, Birkbeck College, and the Universities of East Anglia, Essex, and Cambridge. 
